European journal of American studies

Special Issue: Women in the USA

\title{
The Nurse, the Veteran, and the Female Scientist: Dependency and Separation
}

\section{Kirsten Twelbeck}

\section{(2) OpenEdition \\ Journals}

Electronic version

URL: https://journals.openedition.org/ejas/10761

DOI: 10.4000/ejas.10761

ISSN: 1991-9336

Publisher

European Association for American Studies

\section{Electronic reference}

Kirsten Twelbeck, "The Nurse, the Veteran, and the Female Scientist: Dependency and Separation", European journal of American studies [Online], 10-1 | 2015, document 2.5, Online since 31 March 2015, connection on 08 July 2021. URL: http://journals.openedition.org/ejas/10761 ; DOI: https://doi.org/ 10.4000/ejas. 10761

This text was automatically generated on 8 July 2021.

Creative Commons License 


\title{
The Nurse, the Veteran, and the Female Scientist: Dependency and Separation
}

\author{
Kirsten Twelbeck
}

1 The Civil War catapulted American women into a position of power and authority that during the antebellum period they had only known, perhaps, in private. Between 1861 and 1865 more than twenty thousand women in the Union and Confederate states engaged in government and regimental Civil War hospitals, both as nurses and matrons. By fighting "disease, infection, and the medical infrastructure itself" they combined the nineteenth-century ideal of born nurturers with a new "soldierly aura" (Schultz, Women at the Front 3). By mid-war this somewhat awkward combination was a standard formula in numerous non-fictional and fictional nursing narratives, a sentimental subgenre that remained extremely popular throughout the nineteenth century and beyond. After 1865, the image of the self-sacrificial female humanitarian, who ignored sectional loyalties for the higher cause of saving lives, was a central emblem of the long-lived, and very powerful postwar discourses of cross-sectional reconciliation and national healing. First inspired by Abraham Lincoln's March 4, 1865, reworking of Psalm 147:3 in his Second Inaugural Address, to "bind up the nation's wounds" was America's peacetime credo for years to come. ${ }^{1}$ Indeed, the praise of female nurses was a mainstay at veteran events, culminating with the 1924 unveiling of the "Nuns of the Battlefield" Memorial in Washington D.C.

2 On a less official level however, postwar reactions to the new female ideal of soldiering caretaker were by far more mixed and ambivalent. In some of the fiction of the day, female relief workers are deeply ambiguous literary figures that pose a threat, not only to the heterosexual order, but also to American culture at large. Together with the concept of male patient, the female nurse is part of a more general gendered constellation that preoccupied American society during the postwar era. Analyzing this constellation inspires a greater understanding of what may be called the American Reconstruction mind. Moving beyond established definitions of this era as social, 
political, and economic transformation process, this article casts the two decades following the war as a time of mental adaptation (cf. Butler 173) for a generation that consisted, in large part, of survivors and relatives of survivors (cf. Faust xi-xviii). While technological modernization, secularization, and immigration had a major impact on this generation, one must not forget the lasting anxieties and anger that also influenced the minds, feelings, and decisions of the men and women who had lived through America's bloodiest conflict. This article investigates the gendered dimension of these mental and emotional states. By reading three very different Reconstruction novels and one short story against the backdrop of official veteran memorial culture it sheds light on one of the key functions of this multifaceted literature: driven by gendered tension and anxieties it was a major contribution to the individual and collective adaptation and negotiation process that at least in part challenged or subverted the official celebration of the traditional male heroic ideal (Hochbruck 50-53). Read while elsewhere large-scale ceremonies of sectional reconciliation celebrated the social relations of antebellum America, this literature reminded readers that a return to earlier gender and race relations was neither realistic nor desirable.

3 The following pages discuss a body of works that are usually not read together: Louisa May Alcott's novella Hospital Sketches, Silas Weir Mitchell's short story “The Case of George Dedlow," Alonzo F. Hill's novel John Smith's Funny Adventures on a Crutch, and Mary Bradley Lane's Mizora. The former was first published in 1863 and is therefore not commonly perceived as a contribution to Reconstruction culture. Importantly, however, it was after the war that Hospital Sketches gave rise to controversy as it was accused of its "laxity of tone" and "sad want of Christian experience." 2 This, however, did not impress readers: the book's protagonist, the adventurous and cheerful nurse Periwinkle became a model for an entire generation of young women; the novel remained highly successful until the end of the century. An unruly yet patriotic and good-naturedfemale, Alcott's fictional nurse was an important step toward the influential new-type of the tomboy (cf. Brodhead 69-106). Interestingly, however, it wasn't just Alcott (what else was one to expect from the daughter of one of America's most notorious troublemakers, Bronson Alcott?) who interfered with the postwar atmosphere of patriarchal resurgence: Silas Weir Mitchell's "The Case of George Dedlow" is a particularly disturbing and straightforward expression of postwar anxieties from a male perspective. Published in 1866 in The Atlantic Monthly, Mitchell's short story about an ex-soldier who lost both arms and both legs in the war marks an ideological break with nineteenth-century norms of masculine ideals. Importantly, however, Mitchell's dark humor was a rare exception among his male writercolleagues: popular authors like Alonzo F. Hill eagerly defended Victorian concepts of healthy maleness by resorting to literary slapstick. In line with the male ideal of early veteran culture, Hill's novel about a one-legged veteran, John Smith's Funny Adventures on a Crutch (1869), celebrates the ex-soldier's unbroken sense of adventure and patriotism and was met with much critical acclaim. While Hill's and Mitchell's male survivors represent very distinct and different positions within the male discourse of veteran culture, both point to a deep alienation between the genders. This alienation is nowhere so visible as in Mary Bradley Lane's proto-fascist celebration of gendered, racial, and moral purity that was first published in serial form (1880-1881) in the Cincinnati Commercial. The text did not create the public stir that the author herself had reckoned with when she chose to conceal her true name from the public: during the 
time of its emergence Mizora was merely another contribution to that discourse on male impotence and female takeover that had become a routine topic since the wartime period. What historical and social circumstances kept these tensions around gender, health, and power alive?

4 During the American Civil War, the so-called angels of the battlefield (a term that was first used to refer to Clara Barton, one of the most prolific Civil War nurses) served as a particularly powerful point of reference for American feminists who lamented the continued exclusion of women from the workplace and political decision-making processes. $^{3}$ The ignorance and downright rejection that a lot of female nurses first encountered when they rushed to help in the wards of Civil War hospitals became a major issue in their private and public reports about an ungrateful and self-centered male establishment. This is supported by the correspondence of Daniel Holt, a surgeon in the Union Army. In an 1863 letter to his wife he laments the presence of women in the hospital and proclaims that "if left alone, we will in a short time show you how well men can get along without the aid of women" (Holt 165). While there was certainly reason for doctors to be unhappy with nurses who ignored established hierarchies on the basis of a higher calling, it is important to see that the tensions between male physicians and female nurses soon abated as women became an indispensable and accepted part of the wartime hospital staff. Over the course of the war, surgeons openly welcomed female relief workers "to the point of lobbying the Surgeon General for the right to select their own (staff) as they saw fit" (Leonard, Yankee Women 20). This increasingly positive evaluation was supported by extensive media coverage about particularly outstanding personalities in the field; among them, the courageous and self-sacrificial Clara Barton, who I mentioned earlier, and the fearless and outspoken "Mother" Bickerdyke, who both rose to national fame during the war (cf. Freemon 57). Female relief workers themselves actively contributed to this mythmaking process: according to an estimate by Jane E. Schultz, women wrote sixty-six monographs about their experiences as nurses, forty-two of which were submitted for publication ("Performing Genres" 78). ${ }^{4}$ Fashioning themselves as "surrogates for absent wives, sisters, and mothers" (Schultz, Women at the Front 96) among helpless "boys" (Schultz, Women at the Front 5; 52-55), these highly literate, mostly middle-class women created a popular narrative about female nurses triumphantly saving souls, as well as bodies (Schultz, Women at the Front 216). ${ }^{5}$ This narrative remained very much en vogue until the late nineteenth century, when the feminist ideal of the New Woman entered both American literature and lives.

5 Importantly, however, the image of the nurse as icon of female agency was cast as a temporary arrangement, and while some men changed their view over the course of the war (see, e.g. Bennitt), the female nurse remained an ambivalent concept. Importantly, it was only "grudgingly" that both nurses and doctors had "accepted the idea that the other hoped to be of service and might perhaps, on occasion, actually help the sick and wounded" (Freemon 48). As Elizabeth Massey has pointed out in her analysis of the very last year of the war, nurses "had won over some, but not all, of their earlier opponents"in both the hospital and among the more conservative segments of American society (44).

6 The gendered divide remained virulent even after the war, when nursing the sick was once again an activity that belonged in the domestic sphere. But something had 
changed: after the victory of the Union Army, life for many ex-soldiers remained tough; as Ambrose Bierce (aptly) put it, their generation was "sentenced to life" (qtd. in Morris 205). The newly emerging veteran culture created some solace by celebrating the home-comers as heroes who had bravely fought for the Union or Confederate cause. And yet, there was no denying that public recognition could not make these men whole again: postbellum America was visibly marked by injured, amputated, and traumatized men who simply could not go back to normal, no matter how strongly the era's most popular minister, Henry Ward Beecher, urged recently amputated men to just laugh it off. In his only novel, Norwood (1868), a man from Beecher's own, prewar generation, who lost a leg in an accident that was not war-related, serves as a model to the veterans:

"A wooden leg is a good thing [...]; never have to cut my toe-nails on that leg," said Tommy, with a chuckle. "Not much paid out for shoes neither. Go to a blacksmith for my shoes - ho! Ho! Ho! Never have rheumatism in that leg either. Don't catch cold when I git it wet. Toes never cold on that leg - he! He! He!" (151)

7 Significantly, Norwood also demands that women return to their prewar role as angels in the house, and warns female readers against continuing their wartime work among the needy (cf. 103-04). ${ }^{6}$ That Beecher mentions and discusses this in his novel indicates the postwar crisis of gender and suggests that the war had a different effect on American women, who, for all their suffering and mourning, were invigorated by individual experiences of female agency and the triumph of gradual recognition (cf. Twelbeck). When the war was over, many women who had worked as nurses in Civil War hospitals assumed similar caretaking responsibilities among their veteran husbands, fathers, and brothers-making permanent the wartime constellation of female responsibility and care. Fueled by the era's economic strife, some of these former nurses started to ponder the question whether or not their natural talent could not be turned into a career. A few of them took up nursing as a paid profession, while others became a part of the newly emerging healthcare industry. Others discovered new career options in the booming field of white-collar work under the guise of the female helpmate and self-effacing supporter, which made secretarial positions increasingly accessible for women:

Prewar judgments about middle-class women's frailty and emotional instability, and about the impropriety of their dealing with blood, wounds, ailing bodies, and death outside of the family gave way to increasingly positive evaluations of women's various strengths, and of the potential benefits the sick and wounded might derive from exposure to women's "natural" caretaking talents. By requiring women who had previously devoted their managerial skills to the proper maintenance of bourgeois households [...] the war also dictated men's adaptation to women's sharing of bureaucratic power. (Leonard, Yankee Women xxiii)

8 Since the end of the war in 1865 (and especially after African American men were given the vote in 1870), women of the Civil War generation had angrily lamented their exclusion from higher learning, professional careers, and politics. In their 1881 book History of Woman Suffrage, Elizabeth Cady Stanton, Susan B. Anthony, and Matilda Gage reflected on female relief work by yielding"a narrative about progress in which a collective experience of war had prepared women to assume the reins of reform movements that would energize American political life for several decades" (Schultz, Women at the Front 2). Stanton's appraisal is all the more interesting as it emerged at a time when membership in the Great Army of the Republic (G.A.R.), which was 
composed of Union Army veterans, peaked (cf. Hochbruck 255). But for feminists like Stanton, this was not a time for celebrating the patriotic deeds of men. As she also proclaims in the History:

Woman must lead the way to her own enfranchisement, and work out her own salvation with a hopeful courage and determination. [...] She must not put her trust in man in this transition period, since while regarded as his subject, his inferior, his slave, their interests must be antagonistic. (qtd. in Woloch 89)

9 Stanton had first voiced this separatist credo under the impression of the 1867 Kansas referendum: aimed at removing franchise restrictions on the grounds of both race and sex, the latter had failed (cf. Simon and Danzinger 2). It is in this context, then, that the 1869 beautifully bound, new gift-edition of Alcott's Hospital Sketches found more readers than ever before. It was then that Nurse Periwinkle (a.k.a. "Trib"), that heroic, but not so selfless hospital angel conquered the living rooms of the new nation. Defining herself "a woman's rights woman" (Alcott 11), Trib relies on a well-rehearsed repertoire of female make-believe whenever she needs it. Fashioned after the author herself, she is a woman who refuses to know her place and who replaces the soldiers' "lively accounts of the battle" with an alternative narrative of the traditional male-to-female hierarchy. Trib seems to get something out of nursing and consoling the wounded, and watching over their deathbeds late at night. There is a somewhat sardonic sense of humor bordering on condescension when the narrative describes an amputee as a "one-legged phantom hopping nimbly down the room" (52) and refers to another patient as "a head decorated with a yellow cotton night cap, rendered most imposing by a tassel like a bell-pull" (53).

10 It is very probable that Alonzo Hill, the author of the equally successful Our Boys; Or, The Personal Experiences of the Author while in the Army (1864), had read Hospital Sketches before he published John Smith's Funny Adventures on a Crutch. A picaresque novel written in an anecdotal, humorous, and open-ended form, Funny Adventures counters Periwinkle's latently condescending, female gaze. Unlike Alcott's maimed patients, the hero of Hill's book, a man named John Smith, is anything but a "supremely ridiculous" "one-legged phantom hopping nimbly down the room" (Alcott 52). Hill's veteran narrator bears his mark with a patriotic sense of humor, and thereby scorns those who ignore his manly vigor. The heir of America's most famous explorer (John Smith) travels from Portland to Washington D.C., and from Cincinnati to Louisville and Chicago, and finally takes a ship via the Panama Canal to San Francisco. While emphasizing the invincibility of its hero, the book relies on slapstick scenes that are additionally highlighted in numerous illustrations, while joking tones and verbal puns underline the novel's entertaining function.

11 Projecting a man who is psychologically invincible, Funny Adventures challenges what Erin O'Connor describes as Victorianism's dominant concept of masculinity, an idea that was "contingent upon physical integrity, that a man was only as complete as his body [...] that an incomplete man was not a true man" (745; see also Haley). Set against this earlier Victorian ideal, the postwar sight of men on crutches signaled not only the demasculinization of the American male, but also embodied national anxieties. In line with the general mindset of the era, it would, therefore, have been proper to feign completeness by wearing a prosthesis. Hill's protagonist, however, resists the 
impulse, and fiercely defends his unhampered sense of masculine individualism by vividly displaying his physical handicap:

I can skate as fast as any one, on my solitary foot, swim as well as I ever could, climb like a squirrel, jump on a saddled horse and ride at any pace I please, place a hand on a fence as high as my head and spring over in a quarter of a second, or walk twenty-five or thirty miles a day - all this with one good leg, a crutch and a cane.

A wooden-double of the one-legged hero, the crutch is more than a mere, lifeless appendix. Both supportive of and an endearing asset to its owner, the crutch helps him brace a door and fend off enemies when he is in danger. In other words, the crutch figures as a phallic sign of unbroken manliness that disrupts the discourse on dismemberment that threatened the traditional place of the male body in American society after the war (cf. O'Connor 745).

13 Funny Adventures replaces the earlier, nineteenth-century ideal of individual wholeness and balance with the powerful image of a community of amputees who take possession of American streets as if it were a wartime regiment on an outing: "it was not unusual at all to see fifty or sixty one-legged men stroll in through the grounds in fine weather; or squads of fifteen or twenty [...] clambering upon a street car and going into the city for a bit of a spree" (Hill 18). This somewhat aggressive display of wartime damage is cleverly juxtaposed with civilians' voyeuristic obsessions with war-inflicted injuries. By repeating the stereotypical questions the protagonist has to endure, the novel exposes the naiveté of non-combatants:

"Did you lose your limb in battle? - What battle? Did a cannon ball take it off? A rifle ball, eh? Did it knock it clear off? Did it sever an artery? Did it hit the bone? Did it break it? Did you afterward find the ball? Was it crushed out of shape? [...] Did you feel much pain? [...] Can you wear an artificial leg? [...] How does a person feel with a leg off? [...] Would you rather lose a leg than an arm?" (50)

Randomly strewn across the narrative, these silly questions shame those curious noncombatants who "never went into danger enough to lose a limb" (38). In a metaphorical re-mapping of the nation, the one-legged veteran resumes the work of the historical John Smith and combines his visits of established tourist sites (Niagara Falls, Bunker Hill, Cave City) with trips to Antietam (where he "spent an hour or two traveling about in search for the spot on which I had received my wound") and to the otherwise insignificantSmoketown (where he "had lain in the hospital") (91). The man with the crutch, in other words, reinterprets the American Tour of earlier decades as a recreational passage toward a new, postwar American self. Importantly, this is not an individual undertaking but a promotional tour for all those other "John Smiths" who "had been literally hacked to pieces during the war" (173):

The number of plain John Smiths on the Doctor's book is quite astounding, to say nothing of the innumerable John A., John C., John D., John E., John F., John G., John I., John J., John L., John M., John N., John O., John P., John Q., John R., John S., John T., John U., John V., John W., John X., John Y., and John Z., Smiths! (174)

15 In Funny Adventures, the John Smiths of America appear as the defining norm of a society on the move. The environment that the one-legged veteran travels through is an exaggerated version of a public sphere almost entirely devoid of women: if female characters appear at all, they fail to meet the middle-class standards of moral guardians. Instead of contributing to a better society, they disrupt the protagonist's 
sense-of-self by pitying his physical state. That this is a gross misconception becomes clear when the veteran encounters Mrs. Pheel, a "corpulent" Irish immigrant, who is "given to the moderate use of aqueous stimulus" (865). Drinking, swearing, and attacking another guest in a bar after her intoxicated American husband has left her, Mrs. Pheel is rescued by the one-legged veteran: a soldier on vacation he is the only person in the room who can adequately handle this very un-Victorian, but supposedly very real, example of the state of American post-Civil War womanhood.

16 With its essentially moral view of American postbellum society, Funny Adventures not only reads like a critical comment on Alcott's disrespectful remarks on amputees, but also like a defiant response to the widely-read short story "The Case of George Dedlow." This much darker narrative about a veteran amputee missing both arms and legs was originally published anonymously. It was much later that Silas Weir Mitchellthe "beloved patriarch of modern neurology and even of American psychology" (Long 3)-was identified as the author. "The Case of George Dedlow" is fashioned as the authentic, autobiographical account of a Civil War veteran who struggles for his physical and mental survival. The many nineteenth-century readers who believed the story to be true suggest that after the war, Americans had become so accustomed to physical disfigurement that they were willing-and desperate enough-to believe the most improbable stories of individual survival. Yet, they may also have been wary of the era's "highfalutin" promises of medical innovation, as technology offered no solution to the story's narrator and protagonist: nothing, no modern prostheses, would restore this "fraction of a man" (Mitchell) to his antebellum capacity and manliness (cf. O'Connor 759).

17 It is, significantly, not modern medicine, but literature that enables Dedlow to represent himself most fully. After digging at the notoriously under-developed medical discussion that prevailed in America in the 1860s, "The Case of George Dedlow" praises the Atlantic Monthly for its innovative potential and readiness to publish the story. It is here, and not in a medical magazine, that Dedlow may ponder the quintessential question of a Reconstruction American identity: "how much," he asks, can "a man [...] lose and yet live?" Would "an almost vegetative existence," lacking almost everything that usually defines a body as human, "possess the sense of individuality in its usual completeness," and would this creature be "capable of consciousness?" (114). By giving a voice to a limbless torso, and by describing how this very precarious existence undergoes various physical and mental states, including the self-forgetful state of hypnosis, Mitchell addresses typical male, postwar anxieties during the so-called Second Founding. Physically and mentally exhausted and without a usable past to rely on, George Dedlow not only incarnates the zero point of the veterans' search for individual meaningfulness, but also an alternative concept of community and society. Published three months after the enactment of the 1866 "Act to protect all Persons in the United States in their Civil Rights, and furnish the Means of their Vindication," "The Case of George Dedlow" is fraught with philosophical questions and ideological content in the aftermath of slavery: what defines an American citizen after the War between the States had destroyed much of the foundation US citizenship had been built upon? What are the physical prerequisites for being fully recognized as an individual and a citizen with certain, inalienable rights? What are those who have served their nation-as soldiers or as slaves-entitled to receive, both materially and symbolically, after their "condition of servitude" has officially transpired? Do they have a right to be heard? Who 
represents them if they cannot write, or if they are not mobile enough to state their cause?

18 And yet, "The Case of George Dedlow" is a surprisingly cheerful and optimistic story that sheds the notion of prosthesis and projects a radical alternative to the Victorian male self. Staged as a textual approximation of the veteran's disturbingly damaged life, this equally grotesque and personal testimony hints at an originator, a flesh-and-blood author who incarnates what being a man and a citizen in nineteenthcentury America really means. Dedlow's antebellum self may be dead ("Ded"), and his spirits may be "low" (he does not deny this), but he possesses all that is needed to represent the male self as a public persona: will-power, stamina, and a woman by his side who provides him with everything he needs.

19 In this sense, George Dedlow is not a veteran from the past war, but a man of the future. By explaining how as a handless torso he managed to write his story and how he published it in the nation's most accomplished literary magazine, the narrating I provides readers with an authorized script for a new type of man who makes something of his unique experience. The patient from the Philadelphia "stump hospital" derives his authority from fully acknowledging his personal limits and the realities of his era. Contrary to Hill's veteran on a crutch, Dedlow's journey to manhood begins with a trip to unknown mental territory: in his quest for wholeness, the "strange larval creature" (106) participates in a Philadelphia séance, where he finds out, ironically, that his legs are not ultimately lost, and that he could even have them back as they are preserved in a jar in the American Medical Museum. After suffering a mental breakdown ("It was too much. All that was left of me fainted and rolled over senseless" [123]), Dedlow bravely acknowledges the finality of his situation and relocates to that other, very material and concrete geographical territory that in many ways accords to his socially marginalized and culturally unprecedented, minimal, and entirely open existence: the West. Disillusioned but perfectly clear, the narrative's new man anticipates Mitchell's increasing fondness of this region where, a few decades later, he would send his soonto-become-famous patient Owen Wister. Significantly, however, Dedlow's West defies the late nineteenth-century illusion of the independent male: the "human stump" relies on the help of others as he "dictated these pages, not to shock [...] readers, but to possess them with facts in regard to the relation of the mind to the body" (106).

20 Importantly, this other person is female by implication; the narrative does not even have to mention that the person writing is a woman who cares: embedded in a passage that describes Dedlow's final destination as a place that provides him with "every form of kindness and every possible comfort," the dictation scene takes an iconographic Civil War cliché to the geographical margin of postbellum America. In the literature, personal correspondences, cartoons, and illustrations of the wartime era, the nursewriting-letters-for-the-soldiers had become the powerful mediator figure between military and domestic worlds. While, generally speaking, this was a friendly cliché, it had also been used to less favorable ends: in Alcott's Hospital Sketches, the symbolic crossing of the military-domestic divide serves as a metaphor for the soldiers' endangered manhood. Highly efficient in her treatment of male patients, an energetic Nurse Periwinkle takes "possession" of the patients' "money and valuables," "get[s] the bodies" of these ailing "boys" into "something like order," and writes letters for the physically handicapped (Alcott42). As the chatty nurse confides to the reader there is 
nothing wrong with this all-encompassing female takeover of male bodies and minds: "the letters dictated to me, and revised by me, [...] would have made an excellent chapter for some future history of the war" (Alcott44). Defining herself as an editor rather than a secretary, the narrating nurse refers to the original scribbling of maimed veterans as mere raw material for a female interpretation of the sectional conflict.

21 Mitchell, by contrast, appropriates the image of the nurse's takeover to his own agenda when he turns attention to Dedlow's newly emerging concept of the male self. In his references to his new, Western home, the narrating I admits that his permanent dependency has robbed him of that sense of agency and self-reliance that lies at the bottom of nineteenth-century definitions of American manhood: "I have so little surety of being myself that I doubt my own honesty in drawing my pension, and feel absolved from gratitude to those who are kind to a being who is uncertain of being enough himself to be conscientiously responsible" (124). At the same time, however, the story reclaims the amputated soldiers' authority as owner of his text: "The Case of George Dedlow" is, or purports to be, based on a gendered contract between an educated yet unnamed woman and a male intellectualwho relies on her practical skills to spread his philosophically challenging story. By proposing this division of labor as the story's fundamental raison d'être, "The Case of George Dedlow" confirms the century's almost mathematical equation that associated "the loss of a limb with a proportionate loss of gender" (O'Connor 748); at the same time, however, it anticipates the male-over-female hierarchy that soon became the norm in the late nineteenth-century white-collar workplace. ${ }^{9}$ George Dedlow, in other words, fiercely defends his mental territory through a text that is as phallic and victorious as could be, given the circumstances. It is only to uphold the story's existential claim of truth and authenticity that he hints at a woman holding the pen and filling the lines.

22 Together with other postbellum survivor narratives, "The Case of George Dedlow" and John Smith's Funny Adventures on a Crutch bring to attention an often-ignored dimension of post-Civil War America: the decades following General Robert E. Lee's surrender were orchestrated by cultural artifacts, public rituals, and architectural projects that commemorated the Civil War as a foundational moment in the creation of a truly unified (white [see Blight]) nation. As Wolfgang Hochbruck has shown, much of this culture relied on schematic wartime types (the hero, the adventurer, the soldier with unshakeable composure on the battlefield) and established narrative patterns (e.g., Hill's anecdotal escape to an un-conflicted world of travel and discovery) that ignored the complexities of the sectional conflict. Importantly, however, a part of this culture also addressed unresolved problems, not only on the political plane, but also on the mental one: Civil War veterans were trying to cope with the more immediate physical damage and mental trauma they had brought home from the battlefield, and with a relenting public and feelings of personal shame that threatened their survival.

23 Hill's gassy, one-legged ice skater and Mitchell's "strange" but equally articulate "larval creature" are remarkably spectacular expressions of this collective coping process. Both project and celebrate a new American manhood that derives its masculine vigor, realism, and humanity from that glaring absence that was otherwise seen as a lack of manly, corporeal integrity. And yet, these narratives failed to remove the threat of demasculinization they were meant to banish. Instead, they remained linked to that discourse of the victorious nurse that translated so smoothly into the 
postbellum context. Figuratively speaking, George Dedlow found himself in the grip of an increasingly professionalized healthcare system that was associated with female health activists like Christine Griffin, Caroline E. Lane, Georgeanna Woolsey (cf. Ross 112-13; Starr 155), and Clara Barton, ${ }^{10}$ who had all been nurses in Civil War hospitals. ${ }^{11}$ This, then, went along with Elizabeth Cady Stanton's promotion of a separate path for female careers and her 1868 proclamation that women had a natural affinity with science, which would, in the long run, make them "the governing power of the world." ${ }^{12}$ Such declarations of female independence indicate that profound shift in gender relations that were rooted in American women's experiences during the Civil War and continued well into the twentieth century, culminating in Charlotte Perkins Gilman's all-female utopia, Herland (1915). Yet, Gilman's feminist dream of a happier nation without men seems almost tame in light of Mizora, a feminist separatist utopia written by Mary Bradley Lane, who was a schoolteacher from Ohio. First published in serial form in Murat Halstead's Cincinnati Commercial (1880-1881), the narrative is fashioned as a memoir of one Vera Zarovitch, a Russian exile, who spends fifteen years amongan all-female tribe of enlightened and technologically advanced women. Their perfect world thrives on a notion of permanent quarantine-cut off from the world community, this land is an entirely artificial, but extremely happy, little utopia whose female inhabitants reproduce chemically and spend their lives doing research and furthering their race. These enlightened women do not know private property, but enjoy an institutionalized guarantee of equal access to education and supplies, suggesting a quasi-socialist community. Reminiscent of a late-nineteenth-century sanatorium or college campus, their country consists of recreational grounds, educational buildings, and laboratories. The all-female and all-white inhabitants of this wonderworld embody a principle of absolute purity: hyper-intelligent, breathtakingly beautiful and hyper-healthy, they both fascinate and alienate the dark-haired heroine and lead her to question her own potential to become a part of their superior civilization. (The ambivalent and contradictory character of Vera herself can only be hinted at in this article). ${ }^{13}$

24 Coincidentally, the first installments of Mizora came out at almost exactly the same time as Stanton's History of Women's Suffrage (1881), which includes the first printed version of her aforementioned speech about the Kansas referendum. It was also around this time that membership in the G.A.R.-America's largest Civil War veteran organization-grew to an unprecedented number (Hochbruck 255). It is unknown whether Lane's husband (a man ten years her senior who had fought in the Union Army) and her father (a former Civil War surgeon) were actively engaged in this fraternal organization, but it is clear that she took great pains to leave her husband unaware of her separatist adventures (Pfaelzer, Introduction xiii). Mizora, in other words, tells us little about the actual independence of post-Civil War women, but much about the late nineteenth-century feminist American mind. Published in an era that is not usually associated with Reconstruction as a political, legal, and economic measure to re-integrate the nation, ${ }^{14}$ the novel carries forward the Civil War nursing narrative, turning it into a family saga of female progress and enlightenment that takes the place of an essentially nostalgic and patriarchal veteran culture.

25 Introduced as a tribe that lives three thousand years in the future, the Mizorans are the end product of a long-term selection process that began in a time of political chaos and irresponsibility (after the Civil War). The novel relies on a Darwinian imagery of ill- 
fittedness and natural survival to trace the emergence of an all-female race. Staged as the end-point of a long-term healing process, the society of the blondes relies on an earlier concept of nursing as a patriotic activity, and is closely linked to Abraham Lincoln's definition of Reconstruction as national healing. In Lane's alternative historiography, America had been "diseased from its birth" because it had "lacked the wisdom to remedy" slavery (95). This notion establishes a direct link between individual and collective emotions, moral ideals, and the notion of health in the Mizorans' ideology.$^{15}$ Such rhetoric is perpetuated in the tribe's interpretation of the Civil War as a presumably "healthy" reaction against the "canker that eats into the vitals of any nation that harbors it" (96). In accordance with such metaphors, national healing is eventually accomplished when a corrupt postwar government (reminiscent of the Grant presidency, 1869-1877) collapses, making way for women who "formed a Republic, in which they remedied many of the defects that had marred the Republic of men," particularly, the idea of states' rights (100). Twenty years after Alcott's Hospital Sketches blurred the gender designations of two Civil War figures, "the wounded male soldier and the female nurse" (Young 71), Lane's national healers take the project of "feminizing" American culture to its radical symbolic end: they declare "the exclusion of the male sex from all affairs and privileges for a period of one hundred years" (101). This, then, clears the path for progressive reform based on the value of women's scientific findings and technological inventions, bringing about "some remarkable changes in living, especially in the prevention and cure of diseases" (103). ${ }^{16}$ As the novel emphasizes, this "wonderful change" (94) is the result of that "priceless heritage of health and perfect bodies" of the Mizoran late nineteenth-century foremothers (105). The influence of Francis Galton's Hereditary Genius (1869) is obvious here: according to the famed anthropologist and cousin of Charles Darwin, it was "the most intelligent variety" of humankind that should "prevail in the battle of life," as it was able to fulfill "the needs of centralization, communication, and culture" that secures progress and collective survival (Galton 392). Through Lane's feminist appropriation of the concept, the traditional idea of the natural healer-mother that twenty years earlier had allowed women to work in the all-male wards of the Civil War hospital becomes a natural, female profession. Instead of representing women as patriotic helpmates in the nation-as-hospital, Lane's novel projects a clash of civilizations (a homogenous, healthy female one and a fragmented, diseased heterosexual one) that can only be resolved (healed) by updated, scientific means.

26 The belief in salvation-through-science was very much in line with the secular optimism of the era. Mizora often sounds like an echo of the early American sociologist Frank L. Ward who helped establish the discipline in America during the early 1880 s and who advocated "a planned, or 'telic,' society ('sociocracy') in which nationally organized education would be the dynamic factor" (Cf. "Lester Frank Ward"). Indeed, Ward stated that "[t]he real object of science is to benefit man. A science which fails to do this, however agreeable its study, is lifeless" (Ward qtd. in Henning 88). Adding a feminist slant to these ideas, Mizora imagines freedom from a housewife's daily toil by describing the happy results of their practical research: the happy blondes "di[p] their pretty hands in perfumed water" while "a little machine, with brushes and sponges attached" goes "over the floor at a swift rate" (Lane 44$).{ }^{17}$

27 This vision of a swift and thorough sweep through has a metaphorical dimension as it signals the transition from personal involvement in the morally pure, domestic 
household to an increasingly effective, technologically advanced, work-oriented society. Freed from a housewife's daily chores, Lane's utopians "purify" society through a concerted effort to professionalize social progress. Along with this shift, the female nurse (who extended the idea of domesticity to the hospital) emerges as an oldfashioned yet valid model for that younger generation of female professionals who share her courage, curiosity, moral strength, and patriotic spirit. They, too, are driven by a motherly impulse that they put in the service of a healthy community. At the same time, however, Lane's ideal blondes are devoid of that presumably "womanly" altruism that authorized the work of female volunteers among sick soldiers: while Alcott's narrating nurse at least pretends to be driven by a self-effacing desire to save the wounded, the utopians seek individual self-fulfillment while bettering their perfect world. In line with Victorian notions of feminine frailty Periwinkle eventually falls ill and is forced to return to her father's house. Lane's protagonist, Vera, also leaves the land of her dreams. But unlike Periwinkle she continues her adventurous expedition into the unknown. In line with Darwinian notions of adaptation she successfully moves up and down the evolutionary ladder and sails to America where she embarks on a moral mission for social change. Unlike Nurse Periwinkle, Vera returns to the real world where "ignorance, poverty, and disease" (147) rule supreme. Interestingly, her "cure" for late nineteenth-century America does not entail female self-sacrifice and care but a "universal" and "free" education that will eventually enable society to perfect itself. Yet according to Mizora, collective enlightenment comes at the prize of male elimination: in line with the novel's feminist appropriation of Social Darwinism, disease and crime lie in "his blood" alone (147) and will vanish as soon as men have collectively lost the evolutionary race for knowledge, health, and self-perfection.

28 Importantly, this radical departure from the heterosexual contract was a reaction against the highly visible culture of Civil War remembrance; in 1885, membership in the G.A.P. (the veteran association of the Grand Army of the Republic) reached an unsurpassed peak (Hochbruck 255). Yet instead of supporting this essentially nostalgic movement, Mizora stages the cross-sectional bloodshed as hopeful starting point for the total "feminization" of American society. Interestingly, however, fantasies of gendered segregation were not limited to radical feminists like Lane: more than ten years earlier, Alonzo F. Hill-who wrote for and about the lives of veterans-celebrated the male survivor as indomitable hero, dignified individual, patriot, and true owner of his country. Contrary to Mitchell's "larval creature," John Smith not only escapes from the compassionate care of well-meaning women but removes their gender from the national map while moving across the country. While John Smith's Funny Adventures is of course steeped in the Victorian notion of separate spheres, it also partakes in that mental adaptation process that according to Leslie Butler lay at the heart of Reconstruction. Instead of ignoring the physical dimension of that process, Hill's novel dwells on it as a test case for manly willpower, self-control, and humor.

29 The book's emphasis on the amputee's physical options and potential was a welcome intervention into that depressing story of male dependency and impotence that often preoccupies the maimed and their families. And yet, John Smith's Funny Adventures could hardly bring more than temporary relief to the permanently suffering. The man who knew more about this than any other American was Silas Weir Mitchell, that Civil War surgeon who became famous for his research in neuropathology and the "discovery" of phantom pain among amputees. In "The Case of George Dedlow" he 
explores the relationship between body and mind from the perspective of an amputee who is robbed of the physical prerequisites that define a manly existence. Unlike Hill's hero on a crutch, Dedlow can not compensate the fact that he is, physically and mentally, a "fraction of a man" (124): to tell his story he not only depends on the practical help of a literate women but has to publicly acknowledge his impotence. "The Case of George Dedlow," in other words, is also a story about male shame and the veterans' fear of failing to construe an independent postwar self.

30 Importantly, however, George Dedlow is by far happier in his new frontier home than among that feminized circle of East Coast spiritists he had turned to earlier, in an effort to reclaim his limbs during a séance. Being in the West allows him to represent himself more fully than elsewhere-even if he relies on a woman as his mouthpiece. For his creator, Silas Weir Mitchell, this point of refuge for damaged men was apparently more than a fiction: in $\mathbf{1 8 8 5}$ he advised his patient, Owen Wister, to restore his health in the West. Far removed from the stifling influence of his neurotic mother-a famous reformer-Wister wrote The Virginian (1902), a novel that projected a new type of man, a silent, noble hero. The "Virginian" does not care about the norms and vanities of East Coast society, and follows his own laws-the laws of the West that took their start in the gender wars of Reconstruction America.

\section{BIBLIOGRAPHY}

Alcott, Louisa May. Hospital Sketches. Boston: James Redpath, 1863. 30 December 2014. http:// digital.library.upenn.edu/women/alcott/sketches/sketches.html.

---. Hospital Sketches; and, Camp and Fireside Stories. Boston: Roberts Brothers, 1869. 30 December 2014. https://archive.org/details/hospitalsketche00alco.

Beecher, Henry Ward. Norwood: Or, Village Life in New England. 1868. Reprint. New York: Charles Scribner, 2010.

Bennitt, John. 'I Hope to do my Country Service': The Civil War Letters of John Bennitt, M.D., Surgeon, $19^{\text {th }}$ Michigan Infantry. Detroit: Wayne State UP, 2005.

Blight, David W. Race and Reunion: The Civil War in American Memory. Cambridge: Harvard UP, 2001. Brodhead, Richard. Cultures of Letters: Scenes of Reading and Writing in Nineteenth-Century America. Chicago: U of Chicago P, 1995.

Butler, Leslie. "Reconstructions in Intellectual and Cultural Life." Reconstructions: New Perspectives on the Postbellum United States. Ed. Thomas J. Brown. New York: Oxford UP, 2006. 172-205.

Clinton Catherine, and Nina Silber, eds. Battle Scars: Gender and Sexuality in the American Civil War. New York: Oxford UP, 2006.

Crompton, Samuel Etinde. Clara Barton: Humanitarian. New York: Chelsea House, 2009.

Culpepper, Marilyn Mayer. Trials and Triumphs: Women of the American Civil War. East Lansing: Michigan State UP, 1991. 
Diffley, Kathleen. Where My Heart is Turning Ever: Civil War Stories and Constitutional Reforma, 1861-1876. Athens: U of Georgia P, 1992.

Eiselein, Gregory. Literature and Humanitarian Reform in the Civil War Era. New York: Cambridge UP, 1996.

Faust, Drew Gilpin. Mothers of Invention: Women of the Slaveholding South in the American Civil War. Chapel Hill: U of North Carolina P, 1996.

Freemon, Frank R. Gangrene and Glory: Medical Care During the American Civil War. Chicago: U of Illinois P, 1998.

Galton, Francis. Hereditary Genius: An Inquiry into its Laws and Consequences. London: McMillan Co., 1869.

Haley, Bruce. The Healthy Body and Victorian Culture. Cambridge: Harvard UP, 1978.

Henning, Christoph. "Naturalistic Values and Progressive Politics: A Missing Link Between Pragmatism and Social Theory." European Journal of Pragmatism and American Philosophy 4 (2012): 84-106.

Hill, Alonzo F. John Smith's Funny Adventures on a Crutch, or, The Remarkable Peregrinations of a OneLegged Soldier. Philadelphia: J. E. Potter, 1869.

Hochbruck, Wolfgang. Die Geschöpfe des Epimetheus: Veteranen, Erinnerung und die Reproduktion des amerikanischen Bürgerkriegs. Trier: WTV, 2011.

Holt, Daniel M. A Surgeon's Civil War: The Letters and Diary of Daniel M. Holt, M.D. Kent, OH: Kent State UP, 1994.

Lane, Mary E. Bradley. Mizora: A Prophecy: An 1880s Radical Feminist Utopia. Ed. Jean Pfaelzer. New York: Syracuse UP, 2000.

Leonard, Elizabeth D. Yankee Women: Gender Battles in the Civil War. New York: Norton, 1994.

---. All the Daring of the Soldier: Women of the Civil War Armies. New York: Norton, 1999.

“Lester Frank Ward.” Encyclopedia Britannica. Online 30 December 2014. <http://

www.britannica.com/EBchecked/topic/635784/Lester-Frank-Ward>.

Long, Lisa A. Rehabilitating Bodies: Health, History, and The American Civil War. Philadelphia: U of Pennsylvania P, 2004.

Massey, Mary Elizabeth. Bonnet Brigades: American Women and the Civil War. NY: Knopf, 1966.

Mitchell, S. Weir. “The Case of George Dedlow.” Atlantic Monthly 18.105 (July 1866): 1-11. 30

December 2014. <http://www.gutenberg.org/ebooks/693>.

Morris, Roy. Ambrose Bierce: Alone in Bad Company. New York: Crown, 1996.

O'Connor, Erin. “'Fractions of Men': Engendering Amputation in Victorian Culture.” Comparative Studies in Society and History 39:4 (October 1997): 742-77.

Pfaelzer, Jean. Introduction. Mizora: A Prophecy. An 1880s Radical Feminist Utopia. Ed. Jean Pfaelzer. New York: Syracuse UP, 2000. xi-xl.

Ross, Kristie. “Arranging a Doll's House: Refined Women as Union Nurses.” Divided Houses. Gender and the Civil War. Ed. Catherine Clinton and Nina Silber. New York: Oxford UP, 1992. 97-113.

Satter, Beryl. Each Mind a Kingdom: American Women, Sexual Purity, and the New Thought Movement, 1875-1920. Berkeley: U of California P, 1999. 
Schultz, Jane E. Women at the Front. Hospital Workers in Civil War America. Chapel Hill: U of North Carolina P, 2007.

---. 'Performing Genres: Sarah Emma Edmonds' Nurse and Spy and the Case of the Cross-Dressed Text." Dressing Up For War: Transformations of Gender and Genre in the Discourse and Literature of War. Ed. Aránzazu Usandizaga. Amsterdam: Rodopi, 2001. 73-91.

---. “The Inhospitable Hospital: Gender and Professionalism in Civil War Medicine.” Signs 17.2 (Winter 1992): 363-92.

Simon, Rita J., and Gloria Danziger. Women's Movements in America: Their Successes, Disappointments, and Aspirations. New York: Praeger, 1991.

Starr, Paul. Social Transformation of American Medicine: The Rise of a Sovereign Profession and the Making of a Vast Industry. New York: Basic Books, 1982.

Sweet, Timothy. Traces of War: Poetry, Photography, and the Crisis of the Union. Baltimore: Johns Hopkins UP, 1990.

Twelbeck, Kirsten. "The New Rules of the Democratic Game: Emancipation, Self-Regulation, and the 'Second Founding' of The Unites States." Civilizing and Decivilizing Processes: Figurational Approaches to American Culture. Ed. Christa Buschendorf, Astrid Franke, and Johannes Voelz. Newcastle: Cambridge Scholars, 2011. 175-208.

Ward, Lester Frank. Dynamic Sociology. Vol. I. New York: Appleton, 1883.

Watts, Sheldon. "Die Globale Geschichte der Pocken: Von den Anfängen der Kolonialisierung bis heute," Virus! Mutationen einer Metapher. Ed. Ruth Meyer and Brigitte Weingart. Bielefeld: transcript, 2004. 247-67.

Whites, LeeAnn. Gender Matters: Civil War, Reconstruction, and the Making of the New South. New York: Palgrave Macmillan, 2005.

Wister, Owen. The Virginian. A Horseman of the Plains. 1902. Reprint. New York: Scribner, 2002.

Woloch, Nancy. Women and the American Experience. New York: Knopf, 1984.

Young, Elizabeth. Disarming the Nation: Women's Writing and the American Civil War. Chicago: U of Chicago P, 1999.

\section{NOTES}

1. Regarding the rhetoric of rehabilitation see Blight and Long. Other texts that touch upon the use of healing as a metaphor during the Civil War include Sweet; Diffley; Eiselein, and Young.

2. These quotes stem from critics that are mentioned, seemingly apologetically, in Alcott's preface to the 1869 edition.

3. Cf. Massey; Clinton and Silber, Battle Scars; Faust; Leonard, Yankee Women and All the Daring; Whites; and Culpepper.

4. She adds that among the 42 " 11 were former Confederate, 31 former Union citizens" (78).

5. Hospital Sketches is a case in point here: the hospital, introduced as a site of "disorder, discomfort, [and] bad management" where "unnecessary strictness in one place was counterbalanced by unpardonable laxity in another," is taken over by the white nurse who gets "the bodies of my boys into something like order" so she can then "minister to their minds" (43). 6. Norwood refers to women who joined the teaching staff in Reconstruction schoolhouses in the liberated South. 
7. All subsequent quotations from the story are drawn from the Project Gutenberg online version, which has no page numbers.

8. For the complete text of the 1866 Civil Rights Act see "A Century of Lawmaking for a New Nation" at http://memory.loc.gov/cgi-bin/ampage?collid=llsl\&fileName=014/ llsl014.db\&recNum=058. The bill was vetoed by President Andrew Johnson but nevertheless became a law because of a two-thirds majority in both Congress and Senate.

9. In the United States, female copyists had been known since 1854, and while they remained in the minority until the last two decades of the century, positions for stenographers, typists and copyists had increasingly been filled with women since the early Civil War years. Cf. http:// www.officemuseum.com/office_gender.htm 30 December 2014.

10. Barton founded the American Red Cross. Before the war she had been one of only a handful of women who worked as copyists in the US Patent Office-a white-collar occupation that had cost her an enormous effort to get into, but that became one of the booming fields of female work after the war. Cf. Crompton.

11. Still, the medical field remained a very male one as it was only a "few former relief workers" who actively "sought training as nurses or physicians in the postwar period." Schultz, "The Inhospitable Hospital" 147-48. And yet, their numbers grew, slowly but surely.

12. Stanton in an August 13,1868, article in Revolution, qtd. in Satter 46. Stanton's statement was a reply to Auguste Comte's claim that "woman" could only "inspire science but was not herself a scientist." See Satter 46.

13. My recently finished book project contains an extensive chapter on Mizora.

14. The official end of Reconstruction is the year 1877 when the newly elected president, Rutherford Hayes, consented to withdraw federal troops from the Southern states as a concession to Democrats.

15. In America, of course, moral notions of illness and contagion had been around since the early colonial era. Cf. Watts.

16. If a minor case of illness occurs, it naturally "never threaten[s] to affect the larger community" since "every mother is a family physician" (109).

17. Since Ward's approach was published two years after the first installment of Lane's narrative, the influence can hardly be direct. As Stanton's 1868 remark on female scientists has shown, however, Lane's idea of a "land of brain workers" (45), who through "careful study, and experiment and investigation" (121-22) have found a formula to live very long, healthy lives, had been around for quite some time.

\section{ABSTRACTS}

The discourse that emerged around the female nurses who served in American Civil War hospitals has been a major topic in the debate about nineteenth-century gender relations. What remains obscure, however, is the genesis of this figure during the postwar period and its influence on late nineteenth-century gender relations. Focusing on the post-1865 period as a time of emotional crisis and mental adaptation (Leslie Butler), this article seeks to analyze and assess the gendered tensions that emerged when the process of "bind 嚂ing wounds" (Abraham Lincoln) became a more permanent occupation than was commonly anticipated. By reading Louisa May Alcott's Hospital Sketches, Silas Weir Mitchell's "The Case of 
George Dedlow," Alonzo F. Hill's John Smith's Funny Adventures on a Crutch, and Mary Bradley Lane's Mizora as contributions to and critical interventions into official veteran memorial culture, this article sheds light on the gendered dimension of the Reconstruction adaptation and negotiation process, and explains why the concept of the female nurse played a crucial role in this development.

\section{INDEX}

Keywords: adaptation, amputations, Civil War, feminism (and science), masculinities, nurses, Reconstruction, veterans

Mots-clés: Abraham Lincoln, Alonzo F. Hill, Clara Barton, Elizabeth Cady Stanton, Francis Galton, Frank L. Ward, Henry Ward Beecher, John Bennitt, Louisa May Alcott, Mary Bradley Lane, Matilda Gage, Owen Wister, Silas Weir Mitchell, Susan B. Anthony, "Mother" Bickerdyke

\section{AUTHOR}

\section{KIRSTEN TWELBECK}

Lohmühlenstraße 60,12435 Berlin; kirsten.twelbeck@engsem.uni-hannover.de 